\title{
Influence of bacterial growth of the overnight culture on the captan- and folpet-induced reversion in the Ames test
}

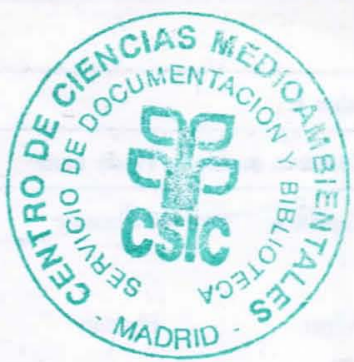

\section{Carmen Barrueco and Eduardo de la Peña}

Instituto de Edafología y Biología Vegetal, Serrano 115 dpdo, 28006 Madrid, Spain

The influence of the stage of bacterial growth of the overnight culture on captan- and folpet-induced reversion in the Ames test was investigated. Tests were performed in order to determine both the number of viable bacteria at different intervals of bacterial growth-in the presence or absence of captan and folpet-and also the number of revertants. Captan or folpet were tested at $5 \mu \mathrm{g}$ per plate, a concentration which had previously showed a mutagenic effect to the TA100 strain. The highest induced reversion was obtained when the bacterial culture used had entered the stationary-phase after $10-14 \mathrm{~h}$, with a titre of at least $10^{8}$ viable cells per $\mathrm{ml}$.

\section{Introduction}

Whenever results obtained in some test systems are not fully reproducible or whenever inter-laboratory variation occurs, then the remedy usually tried is to standardize the test system as much as possible. Although there is a standardized Ames protocol (Maron and Ames, 1983), inter-laboratory, intra-laboratory and even plate-to-plate variability has still been observed.

Belser et al. (1981), found two major classes of factors influencing the test's precision and accuracy: (i) physical effects associated with the manipulation or execution of the test, and (ii) physiological factors such as the interaction between mutagen concentration and volume of S9 (microsome extract) added. Furthermore, the number and physiological condition of the cells plated is an important factor that can also have an influence on the variations which occur between test results (Grafe et al., 1981).

The problem of the number of bacteria per plate and their influence on the number of revertants has been discussed by several investigators. The use of $5 \times 10^{7}$ bacteria per plate has been recommended by a number of authors (Göggelman, 1981; Grafe, 1981; Anderson et al., 1984). Maron and Ames (1983) suggested $2 \times 10^{8}$ bacteria per plate as the optimum number required to achieve maximum test sensitivity. Belser et al. (1981) showed that the relationship between number of cells plated and number of revertants induced by 2 -nitrofluorene in the TA98 strain was not linear. However, they recommended that overnight titres be adjusted to yield inocula of $\sim 1 \times 10^{8}$ cells per plate, thus avoiding even the small amount of variability which can be attributed to inconsistency in the number of cells plated.

The number of spontaneous revertants is independent of the number of bacteria plated within the limits of $10^{5}-10^{8}$ cells (Maron and Ames, 1983). However, spontaneous reversion is strongly dependent on the final number of cells on the plate (Green, 1981). The final number of cells on the plate depends on the histidine supplement added in the top agar (Green, 1981; Barber et al., 1983).

Changes in histidine concentrations affect not only the number of spontaneous mutants but also the number of induced mutants. Aeschbacher et al. (1983) concluded from their experiments that on increasing the histidine concentration in the agar "(1) the number of spontaneous mutants increases slightly; (2) the number of mutants induced by a stable mutagen increases proportionally to the increase of spontaneous mutants; (3) the number of mutants induced by a labile mutagen remains constant or even decreases; and (4) the number of mutants induced by a mutagen, which has to be converted by the bacterial metabolism to the active form, increases very markedly'.

A second aspect has also to be considered. In the Ames test, bacteria from an original culture in nutrient broth medium are brought into a second growth phase on minimum agar. As there is a relationship between the growth phase of the first culture and the duration of the lag-phase in the second culture, it is indicated to use bacteria from the phase with the highest physiological activity and the shortest lag-phase on minimal plates. The bacteria should be taken at a time as close as possible to the logarithmic phase, i.e. at the beginning of the stationary phase (Grafe, 1981). The experiment-to-experiment variability might be improved by using cells in a reproducible metabolic state. Belser et al. (1981) showed that growing cells are about as sensitive to standard mutagens as stationary phase cells, but the dose-response relationship and viable cell titre are more reproducible. The determination of growth curves for the Salmonella strains used will help to determine the optimal incubation period, the duration of which should not extend much into the stationary phase of cell growth (Seiler, 1983a,b).

Grafe (1981) showed that under his culture conditions, TA1535, TA100, TA1538, TA98 and TA1537 strains enter the stationary phase between 6 and $8 \mathrm{~h}$ and that at this point of time the highest number of test cells can be obtained; therefore it cannot be any advantage to wait 16 or $18 \mathrm{~h}$ for taking cells because only a part of the test cells might be able to overcome the lag-phase on minimum agar.

Maron and Ames (1983) recommend a growth period of about $10 \mathrm{~h}$ because it has been observed that viability decreases in most nutrient broth cultures grown longer than $12 \mathrm{~h}$. On the other hand, Barber et al. (1983) demonstrated the inter-dependence of the reversion of the bacteria and their growth on the plates. Thus, agents which affect the growth of the bacteria may change the observed reversion response. Essentially no reversion takes place during the first $4 \mathrm{~h}$ after plating and this phenomenon can have a dramatic effect on the test results for certain unstable compounds. Delayed plating of chemicals should be utilized when the test material is suspected of being unstable under the conditions of the assay.

Finally, the survival measurement in the Ames test becomes important when the toxicity of the compounds plays a significant role (Anderson et al., 1984).

This paper gives the results of experiments carried out to study the influence of bacterial growth of the overnight culture on induced reversion in the Ames test, taking into account the factors previously described, i.e. the number of bacteria plated, the 
Table I.

\begin{tabular}{llllll}
\hline Common name & Trade name & Chemical name & Pority & Source \\
\hline Captan & Orthocide & $N$-[(trichloromethyl)thio]-4-cyclohexene-1,2-dicärboximide & & \\
Folpet & Phaltan & $N$-(trichloromethylthio)phthalimide &
\end{tabular}

Table II. Optical density of the nutrient broth culture, viable bacteria per $\mathrm{ml}$ and revertants per plate at different intervals of incubation time for TA100

\begin{tabular}{|c|c|c|c|c|c|c|c|}
\hline \multirow{2}{*}{$\begin{array}{l}\text { Time } \\
\text { (h) }\end{array}$} & \multirow[t]{2}{*}{$\mathrm{OD}_{650}$} & \multicolumn{3}{|c|}{$\underline{\text { Viable bacteria per } \mathrm{ml}}$} & \multicolumn{3}{|l|}{$\underline{\text { Revertants per plate }}{ }^{\mathrm{a}}$} \\
\hline & & Solvent control & Captan & Folpet & Solvent control & Captan & Folpet \\
\hline 0 & 0.005 & $\begin{array}{c}1.32 \times 10^{5} \\
(5.12)^{\mathrm{b}}\end{array}$ & $\begin{array}{c}2.41 \times 10^{4} \\
(4.38)\end{array}$ & $\begin{array}{c}2.73 \times 10^{4} \\
(4.44)\end{array}$ & $\begin{array}{c}\text { (s) } 27 \pm 10.97^{\mathrm{c}} \\
(1.43)\end{array}$ & $\begin{array}{l}42 \pm 22.63^{c} \\
(1.62)\end{array}$ & $\begin{array}{l}68 \pm 13.75^{c} \\
(1.83)\end{array}$ \\
\hline 1 & 0.010 & $\begin{array}{c}3.59 \times 10^{5} \\
(5.55)\end{array}$ & $\begin{array}{c}4.46 \times 10^{4} \\
(4.65)\end{array}$ & $\begin{array}{c}3.44 \times 10^{5} \\
(5.54)\end{array}$ & $\begin{array}{c}58 \pm 8.89 \\
(1.76)\end{array}$ & $\begin{array}{l}86 \pm 11.36 \\
(1.93)\end{array}$ & $\begin{array}{l}90 \pm 11.36 \\
(1.95)\end{array}$ \\
\hline 2 & 0.012 & $\begin{array}{c}5.25 \times 10^{5} \\
(5.72)\end{array}$ & $\begin{array}{c}2.00 \times 10^{4} \\
(4.30)\end{array}$ & $\begin{array}{c}1.60 \times 10^{5} \\
(5.20)\end{array}$ & $\begin{array}{c}106 \pm 16.97 \\
(2.02)\end{array}$ & $\begin{array}{l}91 \pm 5.29 \\
(1.96)\end{array}$ & $\begin{array}{l}105 \pm 23.26 \\
(2.02)\end{array}$ \\
\hline 3 & 0.025 & $\begin{array}{c}7.23 \times 10^{5} \\
(5.86)\end{array}$ & $\begin{array}{c}9.00 \times 10^{4} \\
(4.95)\end{array}$ & - & $\begin{array}{c}121 \pm 8.74 \\
(2.08)\end{array}$ & $\begin{array}{c}100 \pm 9.16 \\
(2.00)\end{array}$ & $\begin{array}{c}134 \pm 16.82 \\
(2.13)\end{array}$ \\
\hline 4 & 0.152 & $\begin{array}{c}1.16 \times 10^{6} \\
(6.07)\end{array}$ & $\begin{array}{c}1.50 \times 10^{6} \\
(6.18)\end{array}$ & $\begin{array}{c}1.09 \times 10^{6} \\
(6.04)\end{array}$ & $\begin{array}{c}135 \pm 21.55 \\
(2.13)\end{array}$ & $\begin{array}{c}143 \pm 29.74 \\
(2.15)\end{array}$ & $\begin{array}{c}120 \pm 14.57 \\
(2.08)\end{array}$ \\
\hline 5 & 0.425 & $\begin{array}{c}2.80 \times 10^{6} \\
(6.45)\end{array}$ & $\begin{array}{c}1.92 \times 10^{6} \\
-\quad(6.28)\end{array}$ & $\begin{array}{c}1.00 \times 10^{6} \\
(6.00)\end{array}$ & $\begin{array}{c}125 \pm 27.18 \\
(2.10)\end{array}$ & $\begin{array}{c}430 \pm 34.65 \\
(2.63)\end{array}$ & $\begin{array}{c}189 \pm 1.53 \\
(2.28)\end{array}$ \\
\hline 6 & 0.470 & $\begin{array}{c}4.92 \times 10^{6} \\
(6.69)\end{array}$ & $\begin{array}{c}2.11 \times 10^{6} \\
(6.32)\end{array}$ & $\begin{array}{c}2.72 \times 10^{6} \\
(6.43)\end{array}$ & $\begin{array}{c}160 \pm 8.89 \\
(2.20)\end{array}$ & $\begin{array}{c}472 \pm 34.87 \\
(2.67)\end{array}$ & $\begin{array}{l}380 \pm 36.00 \\
(2.58)\end{array}$ \\
\hline 7 & 0.560 & $\begin{array}{c}2.58 \times 10^{7} \\
(7.41)\end{array}$ & $\begin{array}{c}1.24 \times 10^{7} \\
(7.09)\end{array}$ & $\begin{array}{c}1.88 \times 10^{7} \\
(7.27)\end{array}$ & $\begin{array}{c}166 \pm 5.51 \\
(2.22)\end{array}$ & $\begin{array}{c}371 \pm 12.05 \\
(2.57)\end{array}$ & $\begin{array}{l}374 \pm 20.00 \\
(2.57)\end{array}$ \\
\hline 8 & 0.720 & $\begin{array}{c}6.54 \times 10^{7} \\
(7.82)\end{array}$ & $\begin{array}{c}6.30 \times 10^{6} \\
(6.80)\end{array}$ & $\begin{array}{c}1.56 \times 10^{7} \\
(7.19)\end{array}$ & $\begin{array}{c}210 \pm 4.00 \\
(2.32)\end{array}$ & $\begin{array}{l}744 \pm 90.15 \\
(2.87)\end{array}$ & $\begin{array}{l}564 \pm 106.06 \\
\quad(2.75)\end{array}$ \\
\hline 9 & 0.740 & $\begin{array}{c}2.45 \times 10^{8} \\
(8.39)\end{array}$ & $\begin{array}{c}2.16 \times 10^{7} \\
(7.33)\end{array}$ & $\begin{array}{c}3.58 \times 10^{7} \\
(7.55)\end{array}$ & $\begin{array}{c}192 \pm 15.37 \\
(2.28)\end{array}$ & $\begin{array}{c}636 \pm 55.57 \\
(2.80)\end{array}$ & $\begin{array}{l}513 \pm 53.12 \\
(2.71)\end{array}$ \\
\hline 10 & 0.830 & $\begin{array}{c}1.46 \times 10^{8} \\
(8.16)\end{array}$ & $\begin{array}{c}3.36 \times 10^{7} \\
(7.53)\end{array}$ & $\begin{array}{c}5.68 \times 10^{7} \\
(7.75)\end{array}$ & $\begin{array}{c}189 \pm 11.13 \\
(2.28)\end{array}$ & $\begin{array}{l}993 \pm 198.65 \\
(3.00)\end{array}$ & $\begin{array}{c}953 \pm 30.02 \\
(2.98)\end{array}$ \\
\hline 11 & 0.900 & $\begin{array}{c}1.18 \times 10^{8} \\
(8.07)\end{array}$ & $\begin{array}{c}1.52 \times 10^{7} \\
(7.18)\end{array}$ & $\begin{array}{c}3.08 \times 10^{7} \\
(7.49)\end{array}$ & $\begin{array}{c}180 \pm 10.00 \\
(2.25)\end{array}$ & $\begin{array}{c}1180 \pm 20.00 \\
\quad(3.07)\end{array}$ & $\begin{array}{c}1455 \pm 5.03 \\
(3.16)\end{array}$ \\
\hline 12 & 0.990 & $\begin{array}{c}1.00 \times 10^{8} \\
(8.00)\end{array}$ & $\begin{array}{c}2.00 \times 10^{7} \\
(7.30)\end{array}$ & $\begin{array}{c}5.60 \times 10^{7} \\
(7.75)\end{array}$ & $\begin{array}{c}205 \pm 3.21 \\
(2.31)\end{array}$ & $\begin{array}{c}1065 \pm 43.88 \\
(3.03)\end{array}$ & $\begin{array}{c}977 \pm 66.58 \\
(2.99)\end{array}$ \\
\hline 13 & 1.050 & $\begin{array}{l}5.65 \times 10^{8} \\
(8.75)\end{array}$ & $\begin{array}{c}1.50 \times 10^{7} \\
(7.18)\end{array}$ & $\begin{array}{c}9.50 \times 10^{6} \\
(6.98)\end{array}$ & $\begin{array}{c}187 \pm 22.72 \\
(2.27)\end{array}$ & $\begin{array}{c}1461 \pm 11.01 \\
(3.16)\end{array}$ & $\begin{array}{c}930 \pm 127.67 \\
(2.97)\end{array}$ \\
\hline 14 & 1.050 & $\begin{array}{c}1.83 \times 10^{8} \\
(8.26)\end{array}$ & $\begin{array}{c}1.80 \times 10^{7} \\
(7.25)\end{array}$ & $\begin{array}{c}1.40 \times 10^{8} \\
(8.15)\end{array}$ & $\begin{array}{l}176 \pm 22.91 \\
(2.24)\end{array}$ & $\begin{array}{c}1294 \pm 6.03 \\
(3.11)\end{array}$ & $\begin{array}{c}791 \pm 16.29 \\
(2.90)\end{array}$ \\
\hline
\end{tabular}

a The revertant values are given as the $\bar{X} \pm \mathrm{SD}$ of triplicate plates.

${ }^{\mathrm{b}}$ The number in brackets gives the logarithmic transformation of data.

'Small colonies.

growth phase of the bacteria used, the duration of growth period of bacteria and the toxicity of the tested compounds to bacteria using captan and folpet as mutagens.

\section{Materials and methods}

\section{Chemicals}

Captan and folpet were supplied by the US Environmental Protection Agency (EPA).

Table I illustrates names, chemical structure, molecular weight, purity and source of chemicals evaluated.

These compounds were dissolved in dimethylsulphoxide (DMSO; Merck) at a concentration of $50 \mu \mathrm{g} / \mathrm{ml}$.

\section{Bacterial strains}

Salmonella typhimurium strain TA100 was obtained from Dr B.N.Ames, University of California at Berkeley. Its genotype has been described previously by Maron and Ames (1983). To ensure the correct state of the strain, its genetic markers were checked together with other characteristics, such as the response to the standard mutagen and the number of spontaneous revertants.

\section{Method}

The overnight culture of the TA100 strain was prepared from frozen cultures. A $1-\mathrm{ml}$ inoculum was added to bottles containing $100 \mathrm{ml}$ of nutrient broth. The bottles were incubated in a $37^{\circ} \mathrm{C}$ shaking water bath for $14 \mathrm{~h}$ the optical density at $650 \mathrm{~nm}$ (Maron and Ames, 1983), the number of viable bacteria per ml (Anderson et al., 1984) and the number of revertants per plate (Maron and Ames, 1983) were determined hourly. Two separate experiments were carried out.

Viable counts were performed by diluting nutrient broth culture in sterile saline solution and plating $0.1 \mathrm{ml}$ of the diluted culture and $0.1 \mathrm{ml}$ of DMSO or $0.1 \mathrm{ml}$ of the diluted $50 \mu \mathrm{g} / \mathrm{ml}$ solution of captan/folpet on three nutrient agar plates using top agar containing a $0.5 \mathrm{mM}$ biotin $/ 25 \mathrm{mM}$ histidine solution.

Revertant counts were performed by plating $0.1 \mathrm{ml}$ of the nutrient broth culture and $0.1 \mathrm{ml}$ of DMSO or $0.1 \mathrm{of} 50 \mu \mathrm{g} / \mathrm{ml}$ solution of captan/folpet on three minimal glucose agar plates using top agar containing a $0.5 \mathrm{mM}$ histidine/biotin solution. 


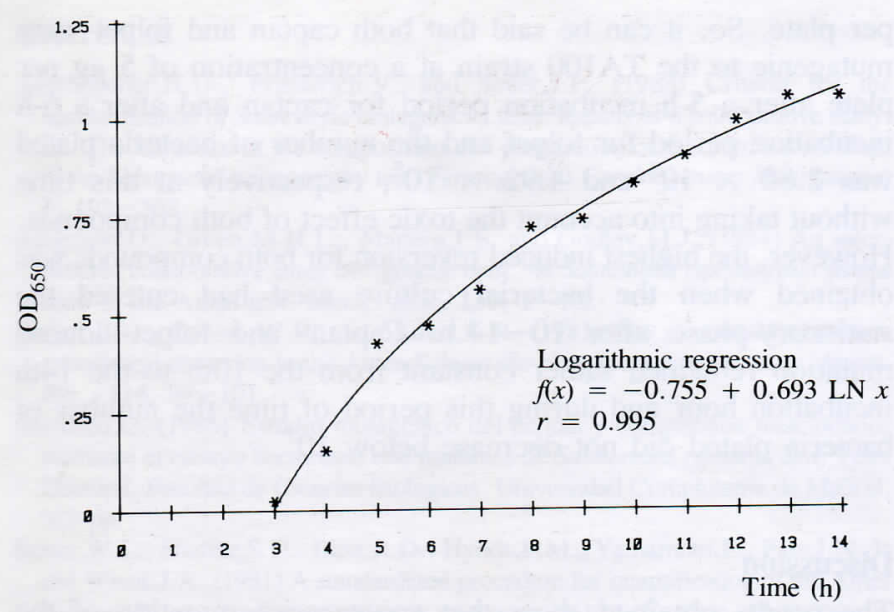

Fig. 1. Growth curve of the TA100 strain in terms of the optical density at $650 \mathrm{~nm}$.

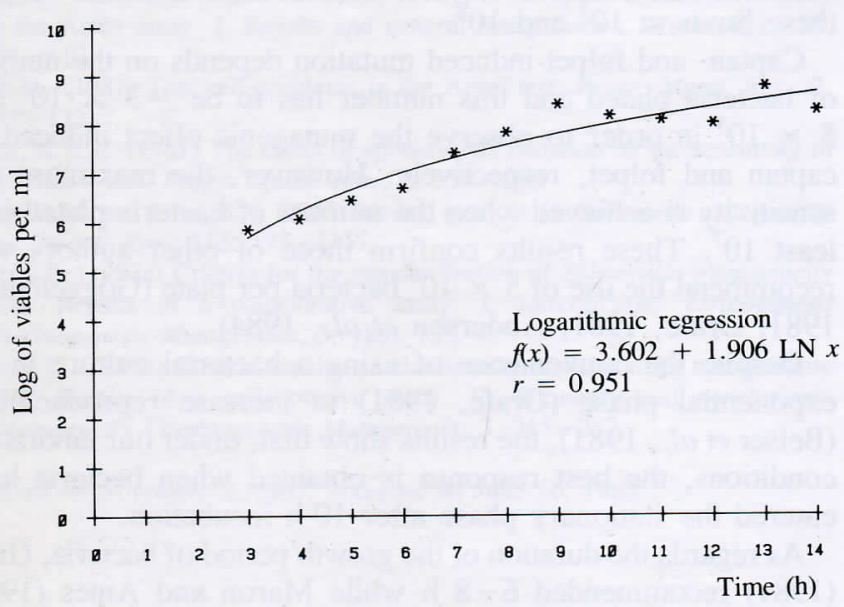

Fig. 2. Growth curve of the TA100 strain in terms of the log of viables per $\mathrm{ml}$.

Plates were incubated at $37^{\circ} \mathrm{C}$ and viable colonies were counted afer $24 \mathrm{~h}$ and revertants after $48 \mathrm{~h}$.

Captan and folpet were tested at a concentration of $5 \mu \mathrm{g}$ per plate which had previously showed a mutagenic effect to the TA100 strain in the standard plate incorporation test (Barrueco, 1986).

\section{Results}

The optical densities at $650 \mathrm{~nm}$ of the nutrient broth cultures, viable bacteria per $\mathrm{ml}$ and revertants per plate at different incubation times are shown in Table II.

Figures $1-4$ show the growth curves and Figures 5-7 the revertants curves.

The curves are derived from fitting data to a logarithmic regression in the case of the growth curves and of the spontaneous mutations, and to a linear regression in the case of the mutations induced by captan and folpet, always taking into account the optimum correlation coefficient in each case.

It can be observed from the growth curves that all of them fit to a logarithmic regression from the 3rd incubation hour, which points to the existence of a lag-phase lasting for $\sim 3 \mathrm{~h}$. As regards the comparison of the growth curves with and without captan and folpet, it may be said that they are very similar and only the small variation on the slope may be taken as an indication of a very weak toxic effect of these compounds on the bacteria. This effect is slightly higher in the case of captan.

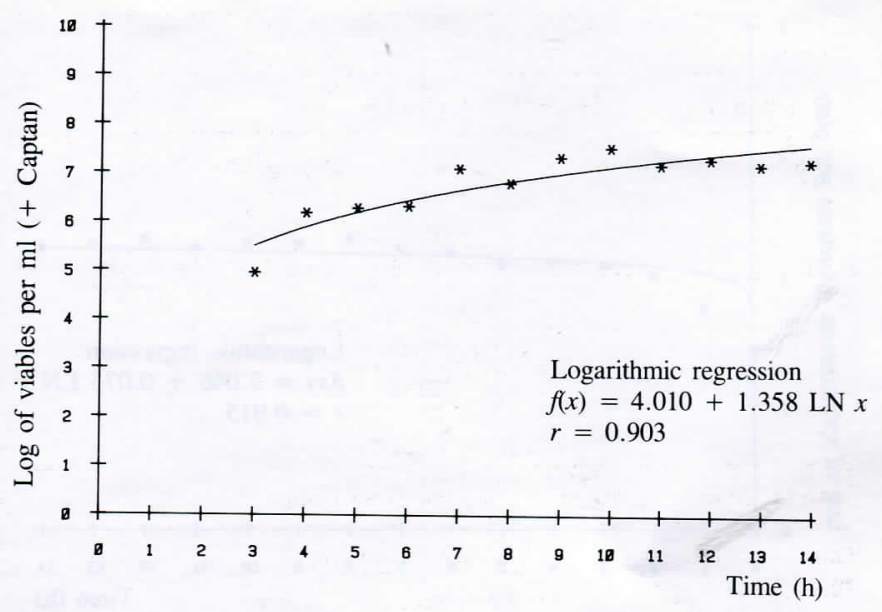

Fig. 3. Growth curve of the TA100 strain in the presence of captan in terms of the $\log$ of viables per $\mathrm{ml}$.

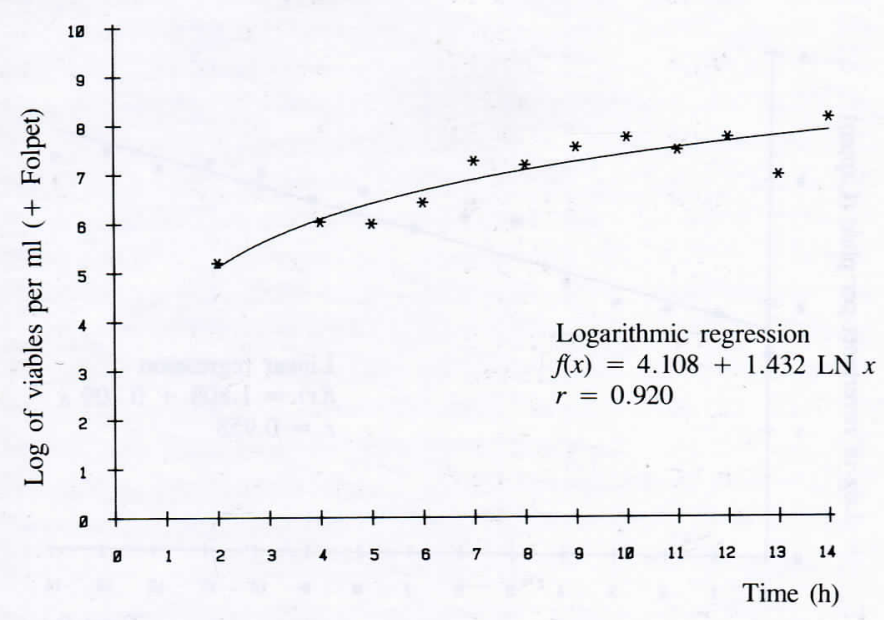

Fig. 4. Growth curve of the TA100 strain in the presence of folpet in terms of the $\log$ of viables per $\mathrm{ml}$.

The growth curves also indicate that bacteria enter the stationary phase within $9 \mathrm{~h}$-if viables are taken into account and $12 \mathrm{~h}-$ if $\mathrm{OD}_{650}$ is taken into account. This discrepancy between the length of log phase can be due to the fact that the optical density is not a reliable measure of the number of viable bacteria in a culture since that measurement is for the total cells, i.e. viables and inviables.

The highest number of viables reached was $5.65 \times 10^{8}$ after a 13-h incubation period. This number was $3.36 \times 10^{7}$ after $10 \mathrm{~h}$ of incubation in the presence of captan and $1.4 \times 10^{8}$ after $14 \mathrm{~h}$ of incubation in the presence of folpet. In all three cases, however, it was observed that the number of viables remained relatively constant from the 9th incubation hour.

Spontaneous mutation remained relatively constant from the 2nd to 14th incubation hour but is lower in the first hours. If the number of viables is taken into account it is observed that when this number is lower than $5.25 \times 10^{5}$, spontaneous mutation of TA100 is also lower. In terms of the number of bacteria plated it can be said that spontaneous mutation is independent of this number within the limits of $5.25 \times 10^{4}$ to $5.65 \times 10^{7}$.

Captan- and folpet-induced mutation depends on the incubation time of the bacteria, which is in turn related to the number of viables per $\mathrm{ml}$ and therefore to the number of bacteria plated. 


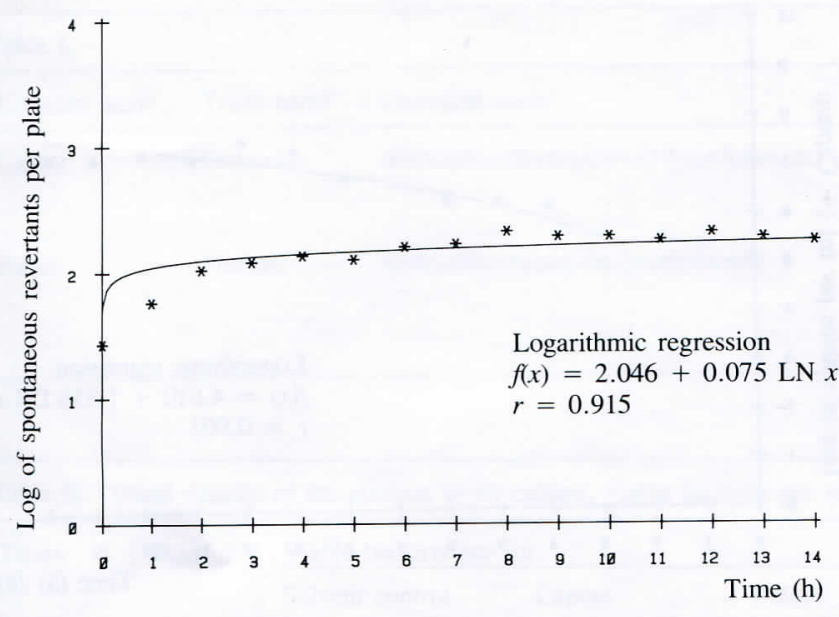

Fig. 5. Influence of the duration of the growth period of bacteria on the spontaneous mutation of the TA100 strain.

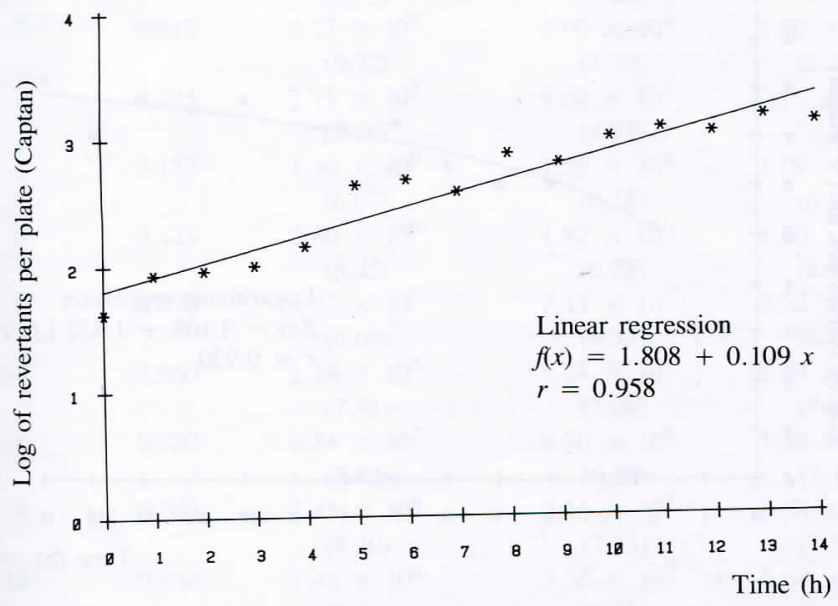

Fig. 6. Influence of the duration of the growth period of bacteria on the mutation of the TA100 strain with captan.

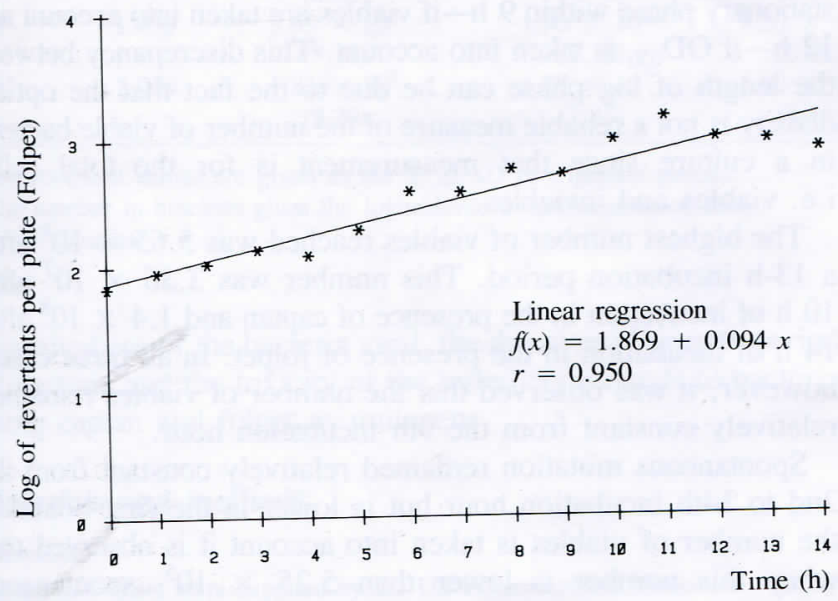

Fig. 7. Influence of the duration of the growth period of bacteria on the mutation of the TA100 strain with folpet.

A concentration of the test compound is considered mutagenic when it produces an increase of 0.301030 in the log of revertants per plate with regard to the log of spontaneous revertants per plate. So, it can be said that both captan and folpet were mutagenic to the TA100 strain at a concentration of $5 \mu \mathrm{g}$ per plate after a 5-h incubation period for captan and after a 6-h incubation period for folpet and the number of bacteria plated was $2.80 \times 10^{5}$ and $4.92 \times 10^{5}$, respectively at this time without taking into account the toxic effect of both compounds. However, the highest induced reversion for both compounds was obtained when the bacterial culture used had entered the stationary-phase after $10-14 \mathrm{~h}$. Captan- and folpet-induced mutation remained rather constant from the 10th to the 14th incubation hour and during this period of time the number of bacteria plated did not decrease below $10^{7}$.

\section{Discussion}

The results obtained show that spontaneous mutation of the TA100 strain is independent of the number of bacteria plated within the limits of $5.25 \times 10^{4}$ to $5.65 \times 10^{7}$ which corroborates the results of Maron and Ames (1983) which set these limits at $10^{5}$ and $10^{8}$.

Captan- and folpet-induced mutation depends on the number of bacteria plated and this number has to be $\sim 3 \times 10^{5}$ and $5 \times 10^{5}$ in order to observe the mutagenic effect induced by captan and folpet, respectively. However, the maximum test sensitivity is achieved when the number of bacteria plated is at least $10^{7}$. These results confirm those of other authors who recommend the use of $5 \times 10^{7}$ bacteria per plate (Göggelmann, 1981; Grafe, 1981; Anderson et al., 1984).

Despite the convenience of using a bacterial culture in the exponential phase (Grafe, 1981) to increase reproducibility (Belser et al., 1981), the results show that, under our laboratory conditions, the best response is obtained when bacteria have entered the stationary phase after $10-\mathrm{h}$ incubation.

As regards the duration of the growth period of bacteria, Grafe (1981) recommended 6-8 h while Maron and Ames (1983) recommended no more than $10 \mathrm{~h}$. In this study, it has been found that between the 10th and the 14th hour induced mutation variations are minimal. For this reason and for matter of convenience, this period may be established as $14 \mathrm{~h}$ in order to determine the mutagenic effect induced by captan or folpet.

On the other hand, the viability test shows that both captan and folpet at a concentration of $5 \mu \mathrm{g}$ per plate yield a $10 \%$ survival in most cases. However, the mutagenic effect observed does not decrease. So, it can be of interest to perform both viability and mutagenicity tests in order to find a range of concentrations in which the mutagenic effect is not masked by toxicity.

In conclusion, captan- and folpet-induced mutation in the TA100 strain is influenced by the state of bacteria. In our laboratory the Ames test should be performed in a standardized procedure by establishing the same bacterial growth period $(10-14 \mathrm{~h})$ after which there will be at least $10^{8}$ viable bacteria per $\mathrm{ml}$ in the stationary phase in order to increase the reproducibility of the effect observed.

\section{Acknowledgements}

The authors thank Mr L.Cuadra for critical reading of the manuscript, Drs E.Valcarce, C.Canga and A.Herrera for their valuable comments, and P.Gutierrez, M.V.Castaño, A.Martinez and F.Sancho for help with the preparation of the manuscript. Special thanks are due to Professor Dr E.Laborda for his direction and to Professor Dr A.Bello for his interest on the publication of this manuscript. This work was funded in part by a FISSS Grant. 


\section{References}

Aeschbacher,H.U., Friederich,V. and Seiler,J.P. (1983) Criteria for the standardization of Salmonella mutagenicity tests: Results of a collaborative study. III. The influence of the composition and preparation of the minimal medium in the Salmonella mutagenicity test. Teratogenesis Carcinogenesis Mutagenesis, 1, 195-203.

Anderson,D., Green,M.H.L., Mattern,I.E. and Godley,M.J. (1984) An international collaborative study of "genetic drift" in Salmonella typhimurium strains used in the Ames test. Mutat. Res., 130, 1-10.

Barber,E.D., Donish,W.H. and Muller,K.R. (1983) The relationship between growth and reversion in the Ames Salmonella plate incorporation assay. Mutat. Res., 114, 89-101.

Barrueco,C. (1986) Estudio mutagenico del captan y compuestos relacionados mediante el ensayo bacteriano con mutantes de Salmonella typhimurium. Tesis Doctoral. Facultad de Ciencias Biologicas. Universidad Complutense de Madrid, $542 \mathrm{pp}$.

Belser,W.L., Shaffer,S.D., Bliss,R.D., Hynds,P.M., Yamamoto,L., Pitts,J.N.,Jr and Winer,J.A. (1981) A standardized procedure for quantification of the Ames Salmonella/mammalian-microsome mutagenicity test. Environ. Mutagenesis, 3, $123-139$.

Göggelman,W. (1981) Culture conditions and influence of the number of bacteria on the number of revertants. Progr. Mutat. Res., 2, 173-178.

Grafe,A., Mattern,B.E. and Green,M. (1981) A European collaborative study of the Ames assay. I. Results and general interpretation. Mutat. Res., 85, $391-410$

Grafe,A. (1981) Test cell problems in the Ames test. Progr. Mutat. Res., 2, $167-172$.

Green,M.H.L. (1981) The effect of spontaneous mutation on the sensitivity of the Amest test. Progr. Mutat. Res., 2, 159-166.

Maron,D.M. and Ames,B.N. (1983) Revised methods for Salmonella mutagenicity test. Mutat. Res., 113, 173-215.

Seiler,J.P. (1983a) Criteria for the standardization of Salmonella mutagenicity tests: Results of a collaborative study. I. Introduction. Teratogenesis Carcinogenesis Mutagenesis, 3, 183-185.

Seiler,J.P. (1983b) Criteria for the standardization of Salmonella mutagenicity tests: Results of a collaborative study. V. Summary and conclusions. Teratogenesis Carcinogenesis Mutagenesis, 3, 215-217.

Received on November 2, 1987; accepted on June 16, 1988 